Dedicated to Prof. Hong-Kun Xu on the occasion of his $60^{\text {th }}$ anniversary

\title{
Solving split generalized mixed equality equilibrium problems and split equality fixed point problems for nonexpansive-type maps
}

\section{O. NNAKWE}

\begin{abstract}
.
Let $X$ be a 2-uniformly convex and uniformly smooth real Banach space. In this paper, an iterative algorithm of Krasnosel'skii-type is constructed and used to approximate a common solution of split generalized mixed equality equilibrium problems (SGMEEP) and split equality fixed point problems $(S E F P P)$ for quasi- $\psi$-nonexpansive maps. A strong convergence theorem of the sequence generated by this algorithm is proved without imposing any compactness-type condition on either the operators or the space considered. The theorem proved improves and complements important recent results in the literature.
\end{abstract}

Acknowledgements. The author thank the anonymous referees for their very useful remarks which helped to improve the final version of this paper.

\section{REFERENCES}

[1] Alber, Y., Metric and generalized projection operators in Banach spaces: properties and applications, Theory and Applications of Nonlininear Operators of Accretive and Monotone Type (A. G. Kartsatos, Ed.), Marcel Dekker, New York (1996), 15-50

[2] Alber, Y. and Ryazantseva, I., Nonlinear Ill Posed problemss of Monotone Type, Springer, London, UK, 2006

[3] Attouch, H., Bolte, J. and Redont, P., et al., Alternating proximal algorithms for weakly coupled minimization problems, applications to dynamical games and PDE's, J. Convex Anal., 15 (2008), No. 3, 485-506

[4] Blum, E. and Oettli, W., From optimization and variational inequalities to equilibrium problems, Math. Student, 63 (1994), No. 1-4, 123-145

[5] Bnouhachem, A., A modified projection method for a common solution of a system of variational inequalities, a split equilibrium problem and a hierarchical fxed-point problem, Fixed Point Theory Appl., 2014, 2014:22, 25

[6] Byrne, C., A unified treatment of some iterative algorithms in signal processing and image reconstruction, Inverse Probl., 20 (2004), No. 1, 103-120

[7] Byrne, C., Iterative oblique projection onto convex subsets and the split feasibility problem, Inverse Probl., 18 (2002), 441-453

[8] Censor, Y., Bortfeld, T. and Marti, B., et al., A unified approach for inversion problems in intensity-modulated radiation therapy, Phys. Med. Biol., 51 (2006), 2353-2365

[9] Censor, Y. and Segal, A., The split common fixed point problem for directed operators, J. Convex Anal., 16 (2009), 587-600

[10] Chang, S. S., Wang, L. and Zhao, Y., Strongly convergent iterative methods for split equality variational inclusion problems in Banach spaces, Acta Math. Sci. Ser. B (Engl. Ed.), 36 (2016), No. 6, 1641-1650

[11] Chang, S. S., Lee H. W. and Chan C. K., A new method for solving equilibrium problem fixed point problem and variational inequality problem with application to optimization, Nonlinear Anal., 70 (2009), 3307-3319

Received: 01.03.2019; In revised form: 28.07.2019; Accepted: 05.08.2019

2010 Mathematics Subject Classification. 47H09, $47 \mathrm{~J} 25$.

Key words and phrases. Nonexpansive-type maps, split fixed point problems, split generalized equaity equilibrium problems, strong convergence. 
[12] Chidume, C. E. and Nnakwe, M. O., A new Halpern-type algorithm for a generalized mixed equilibrium problem and a countable family of generalized-J-nonexpansive maps, with applications, Carpathian J. Math., 34 (2018), No. 2, 191-198

[13] Chidume, C. E., Romanus, O. M. and Nnyaba, U. V., An iterative algorithm for solving split equilibrium problems and split equality variational inclusions for a class of nonexpansive-type maps, Optimization, DOI: 10.1080/02331934.2018.1503270

[14] Chidume, C. E., Ndambomve, P. and Bello, A. U., The split equality fixed point problem for demi-contractive mappings, J. Nonlinear Anal. Optim., 6 (2015), No. 1, 61-69

[15] Giang, D. M., Strodiot, J. J. and Nguyen, V. H., Strong convergence of an iterative method for solving the multiple-set split equality fixed point problem in a real Hilbert space, RACSAM. 2017, doi:10.1007/s13398016-0338-7

[16] Kamimura S. and Takahashi W., Strong convergence of a proximal-type algorithm in a Banach space, SIAMJ. Optim., 13 (2002), No. 3, 938-945

[17] Ma, Z., Wang, L., Chang, S.S. and Duan, W., Convergence theorems for split equality mixed equilibrium problems with applications, Fixed Point Theory Appl., 2015, 2015:31, 18 pp.

[18] Ma, Z., Wang, L. and Cho, Y. J., Some results for split equality equilibrium problems in Banach Spaces, Symmetry, 11 (2019), No. 2, 194

[19] Moudafi, A., Alternating CQ-algorithm for convex feasibility and split fixed-point problems, J. Nonlinear Convex Anal., 15 (2014), No. 4, 809-818

[20] Xu, H. K., Inequalities in Banach spaces with applications, Nonlinear Anal., 16 (1991), No. 12, 1127-1138

[21] Zhang, S., Generalized mixed equilibrium problems in Banach spaces , Appl. Math. Mech. -Engl. Ed., 30 (2009), No. 9,1105-1112 DOI: 10.1007/s10483-009-0904-6

[22] Zhao, J., Solving split equality fixed-point problem of quasi-nonexpansive mappings without prior knowledge of operators norms, Optim. 2014. doi:10.1080/02331934.2014.883515.

INSTITUTE OF MATHEMATICS

AFRICAN UNIVERSITY OF SCIENCE AND TECHNOLOGY

ABUJA, KM 10 AIRPORT ROAD, FCT, GALADIMAWA, NigERIA

Email address: mondaynnakwe@gmail.com 